\title{
Non-Invasive Cribriform Carcinoma
}

National Cancer Institute

\section{Source}

National Cancer Institute. Non-Invasive Cribriform Carcinoma. NCI Thesaurus. Code C162973.

A carcinoma characterized by the presence of a cribriform architectural pattern. There is no evidence of surrounding stromal invasion by the malignant cells. 